\title{
Analysis of Publicly Available Business E-Data in Slovakia
}

\author{
Romana Hricová ${ }^{1,}$, Stanislav Adamčík ${ }^{2}$ \\ ${ }^{1}$ Department of Manufacturing Management, Faculty of Manufacturing Technologies with a seat in Presov, Technical University of \\ Kosice, Bayerova 1, 08001 Presov, Slovakia, romana.hricova@tuke.sk \\ 2 stanislav@adamcik.sk
}

\section{Abstract}

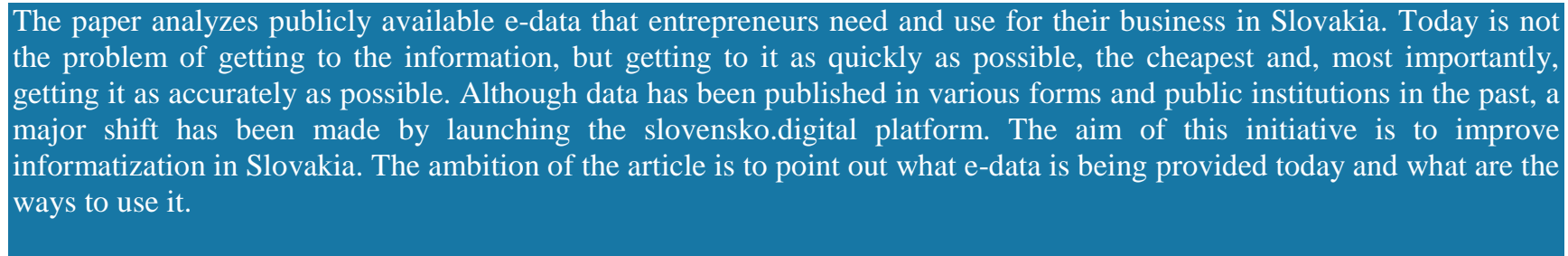

Keywords: E-Data, Consolidation, Dataset, Information.

Received on 08 December 2017, accepted on 20 March 2018, published on 26 June 2018

\begin{abstract}
Copyright (C) 2018 Romana Hricová and Stanislav Adamčík, licensed to EAI. This is an open access article distributed under the terms of the Creative Commons Attribution licence (http://creativecommons.org/licenses/by/3.0/), which permits unlimited use, distribution and reproduction in any medium so long as the original work is properly cited.
\end{abstract}

doi: 10.4108/eai.26-6-2018.154830

\section{Introduction}

Nowadays, entrepreneurs, business entities but also private individuals do not have to deal with a lack of information, but instead choose from the overflow of information the right, relevant ones they need and which will be topical as well. Especially for entrepreneurs, it is sometimes a problem to find information about business partners and to verify their credibility. Truth is that every production unit that wants to be competitive in the present day should be characterized by a suitable combination of needed productivity, flexibility and quality. [1] Obviously, if subjects can choose, they prefer official data sources, but those that are scarce, are not always in the form that individuals prefer or need, and most often are time-lag. That is why the resources provided by independent organizations are increasingly being searched for. Even if they collect data from official sources, they often process, evaluate or link them, which will subsequently make it much easier for people to search.

In 2000 was adopted Act No. 211/2000 Coll. on Free Access to Information and on Amendments to Certain Acts (Freedom of Information Act). [2] The law stipulated which obligated persons must make the information

*Corresponding author. Email: romana.hricova@tuke.sk available. These include state authorities, municipalities, higher territorial units as well as those legal entities and natural persons to whom the law confers the power to decide on the rights and obligations of natural or legal persons in the field of public administration, and only to the extent of their decision-making activities. The need for the law arises because official information is much more valuable than unofficial because the data thus obtained is not only from the sample of respondents but from the basic set, i.e. all respondents who are required to publish this information.

Entities are also faced with the problem of comparing data for each period and thus monitoring economic developments, for example, supplier, competitor or other relevant business. Very important precondition for a successful company application in the business environment is its ability to archive relevant data in the long term on the basis of management quality systems, exactly according to the requirements specified in concrete conditions. [3] It is good if data are available for at least the last 3 years. It is true that the harder the history can be found, the better it is for the search person, because it can create a more comprehensive view.

All these facts, plus the constant pressure on public administration, the growing demands for transparency and accuracy of information in the shortest possible time, have 
A. N. Author, B. N. Author and C. N. Author

yielded results. In its way, 2016 became a breakthrough thanks to the launch of the slovensko.digital platform.

\section{Data providers}

Publicly available data can be obtained from the following groups of providers:

1) state entities,

2) independent organizations,

3) enterprises.

\subsection{State Entities}

The most important sources of published data are:

\section{a) Statistical Office of the Slovak Republic}

The oldest source of published data is Statistical Office of the Slovak Republic. The history of organized statistical surveys on the territory of today's Slovakia extends until 1715 , when a whole-country census of the population was carried out in Hungary. Nowadays its basic missions are to provide statistical information on the state and development of the economy and on social development in the Slovak Republic to legislative and government bodies, state administration bodies, municipalities, the public and foreign users.

The conditions for obtaining the necessary information are regulated by Act No. 540/2001 Coll. on State Statistics, which entered into force on 1 January 2002. Pursuant to this Act, a legal entity or a natural person who is a reporting entity is obliged to provide free of charge, fully, truthfully and within specified deadlines, the data required by the State Statistical Surveys, which are listed in the State Statistical Surveys Program.

Statistical Office offers DATAcube - the classification system of individual tables is based on maintaining the structure of domains and fields similarly as in the web Portal. Data from various statistical fields are presented in the form of multidimensional tables in monthly, quarterly or yearly time series and allow creating your own selections. At the end of the title of each table there is eight-digit code, which is the unique identifier. The outputs can be exported to file formats: PDF and XLS. [4]

In this context, it is important to note that the statistical office provides only very limited information on individual enterprises. By company registration number (IČO) or name, you can search for an organization. The following organizational information will then be shown: Company ID (IČO), business name, date of beginning, date of termination, address, district, municipality, legal form, main activity, institutional sector, type of ownership and size of organization. Since no other information can be found, the only relevant figure is whether the organization exists or not.

Directly on this page is the opportunity to choose "open

data".

The Statistical Office of the Slovak Republic publishes the available data in open formats with a text description of the published data content, based on the Government Resolution of the Slovak Republic No 59/2015 of 11 February 2015 approving the Open Government Partnership Action Plan of the Slovak Republic 2015. [4]

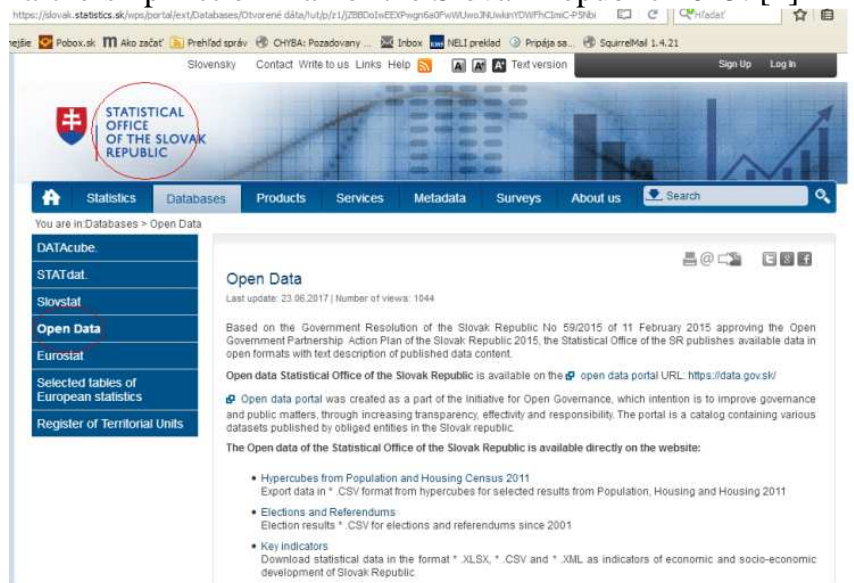

Figure 1. English page of Statistical Office of the Slovak republic with link to open data [4]

b) National Agency for Network and Electronic Services

National Agency for Network and Electronic Services was created within the project: "Electronic Services of Government Office of the Slovak Government eDemocracy and open government", financed from the resources of the European Union. [5] Open data portal was created as a part of the Initiative for Open Governance, which intention is to improve governance and public matters, through increasing transparency, effectivity and responsibility. The portal is a catalog containing various datasets published by obliged entities in the Slovak republic. Data can be collected from the web directly from the published links or by searching. Open data portal is capable to store a copy of data or accommodate them space in database, along with standard visualization tools, according to the type of data (and the forms of use). [5] Specific datasets can be found at https://data.gov.sk/dataset. There are 1243 different datasets from multiple organizations at present (December 2017). Fig. 2 shows English homepage of the Central Public Services Portal for People. [5]

These datasets can be searched for and filtered by organizations, keywords and expressions, file formats, licenses, and the specified sequence on the portal,. Datasets are available in different file formats. The largest representation is CSV and XML. 


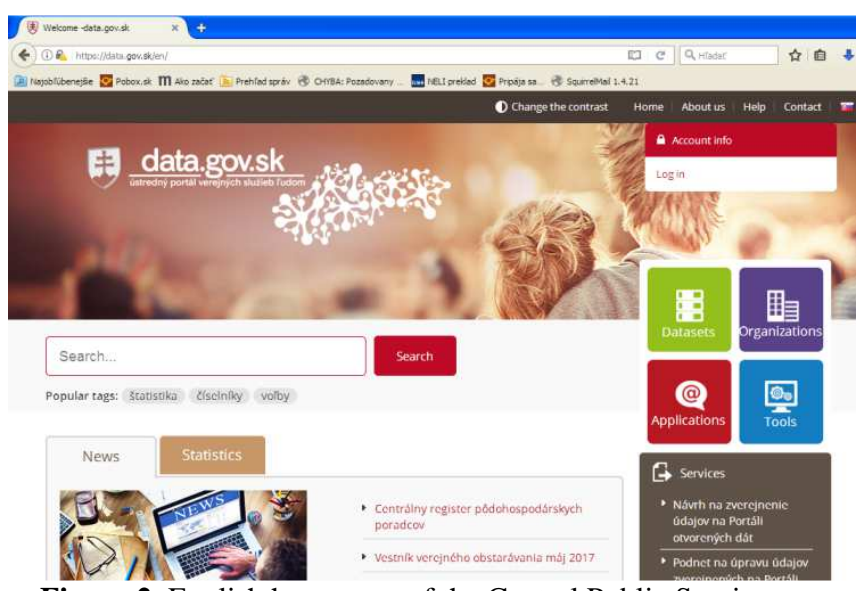

Figure 2. English homepage of the Central Public Services Portal for People [5]

\section{c) Commercial bulletin}

The Commercial bulletin [6] is operated by the Ministry of Justice of the Slovak Republic. According to Act no.200/2011 Coll. on the Business Journal, the Ministry of Justice of the Slovak Republic, as the publisher of the Business Journal, also makes available the data published in the Business Journal in the form of structured data that allows search and their further automated processing. To download structured data, it is necessary to register for free and then download the data on working days from $7.00 \mathrm{pm}$ until $7.00 \mathrm{am}$, on unlimited through non-working days. Published texts are only informative and not legally binding. Data are updating every working day. Provides the following data:

- Commercial register

- Collection of documents

- Notices of initiation of winding-up or co-operation proceedings without liquida-tion

- Bankruptcy and restructuring

- Claims of liquidators

- Other announcements

- Specification of received share of income tax paid

- Auctions

- Sale of property

- Management reports

- Mandatory published contracts

Fig. 3 shows search page of the Commercial bulletin. [6]

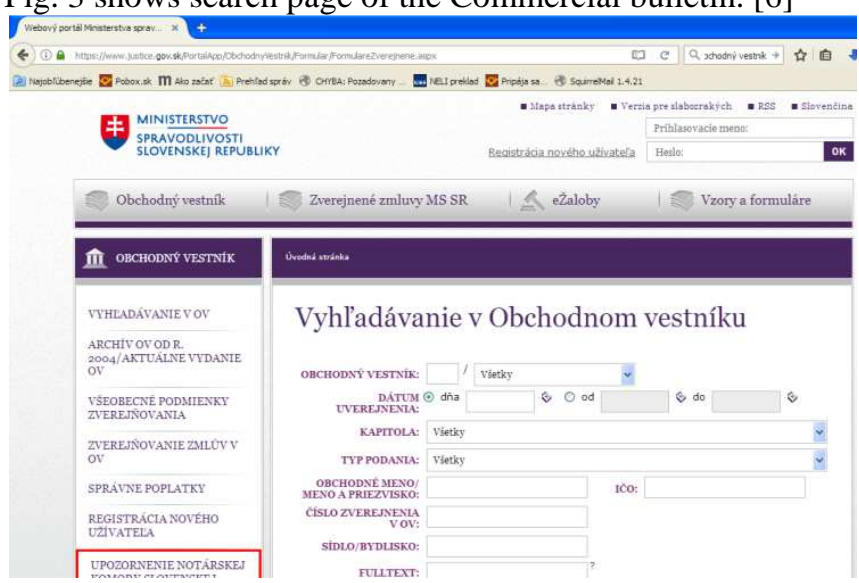

Figure 3. Search page of the Commercial bulletin [6]

\section{d) Social Insurance Agency}

There is only a database of debtors in the page of the Social Insurance Agency. [7] Data is in two formats: TXT and CSV.

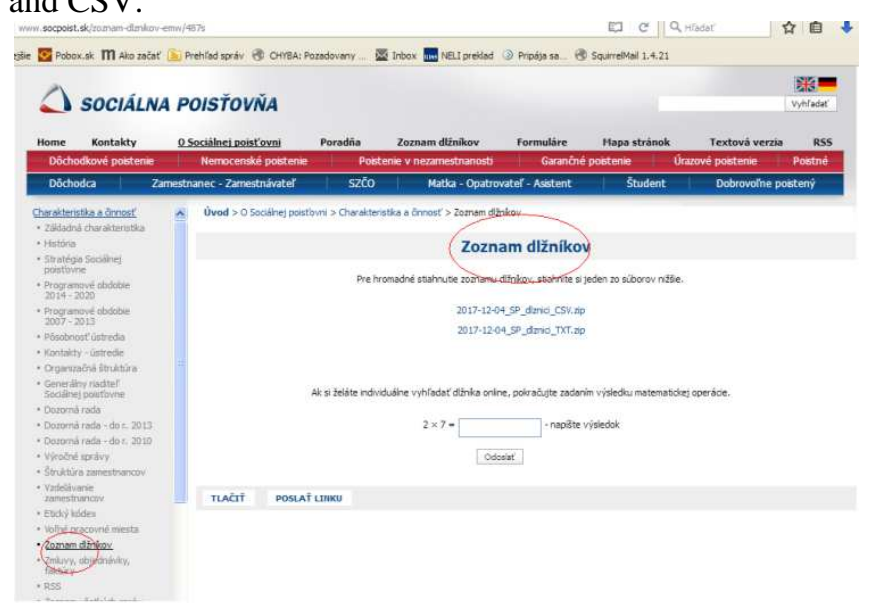

Figure 4. Debtor database search page of the Social Insurance Agency [7]

e) The Ministry of Finance of the Slovak Republic maintains a Register of financial statements [8]. The Register of the Financial Statements was established with the aim of improving and simplifying the business environment and reducing the administrative burden of the business. Simultaneously the Register improves accessibility and quality of the information about the accounting entities. [9] It is possible to find complete accounts in the register by name, company registration number or tax ID and if the company was required to disclose both the annual report and the auditor's report, these are also available. However, a more in-depth investigation will show that not every company is likely to upload the requested data or submit it in the required format as some data shows "Data not available in a structured form." There is homepage of the Register of Financial Statements on the Fig.5. [8]

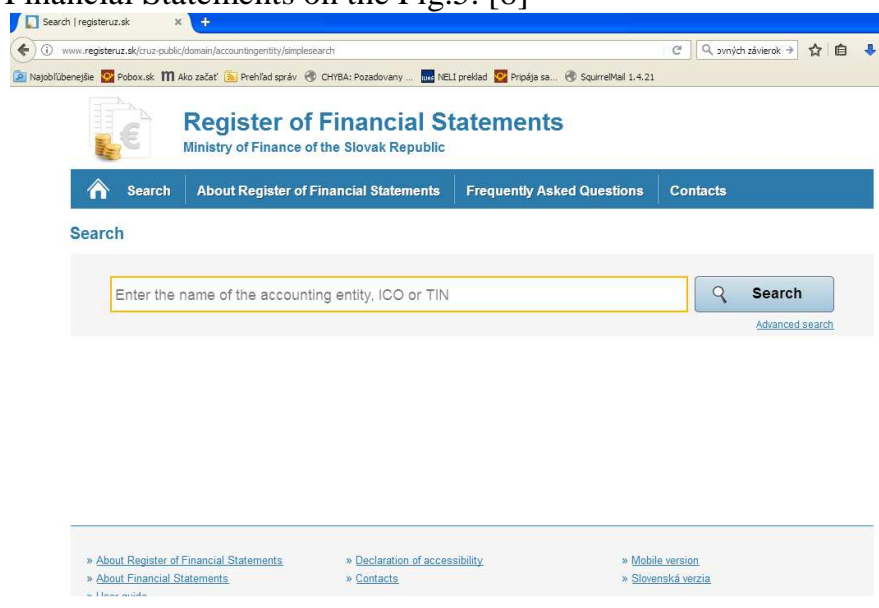

Figure 5. Homepage of the Register of Financial Statements [8] 


\section{A. N. Author, B. N. Author and C. N. Author f) Central Register of Contracts}

The Central Register of Contracts [10] is the website on which contracts concluded by the liable entity (pursuant to $\$ 5 \mathrm{a}$ of Act No. 211/2000 Coll.) are published. [2] A publicly disclosed contract involving the Ministry, the other central state administration body, a public body and a budgetary organization or a contributory organization established by them, which are liable pursuant to Article 2, shall be published in the Central Register of Contracts; The liable entity shall immediately send to the Office of the Government of the Slovak Republic a contract for publication. The Central Register of Contracts is a public list of mandatory contracts, which are maintained by the Office of the Government of the Slovak Republic in electronic form; Register is a public administration information system. In this register is today approx. 1,496,696 contracts (December 2017). Fig.6 shows English homepage of the Central Register of Contracts. [11]

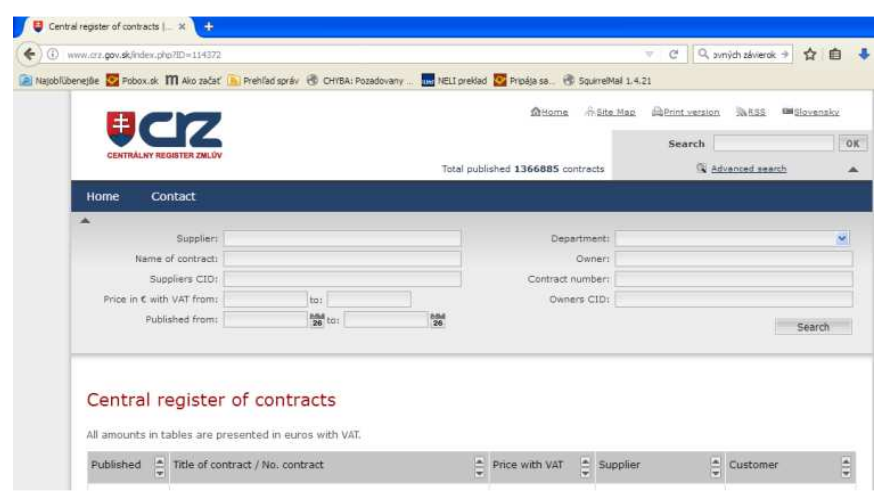

Figure 6. English homepage of the Central Register of Contracts [11]

\subsection{Independent organizations}

These include organizations interested in giving the general public access to publicly available data in a transparent form or in the form of a suitable dataset for further processing. These organizations receive data from the state administration, trying to consolidate them. The most distinguished providers include:

\section{a) Fair-play Alliance}

The Fair-play Alliance is a standard non-profit and non-party civic association founded in 2002 by former journalist Zuzana Wienk [12]. The civic association manages the datanest.sk project [13], which offers various datasets (The English homepage of the Datanest is on the Fig.7). Regularly updated datasets include the Organization's Register, which currently contains over $1,400,000$ entries.

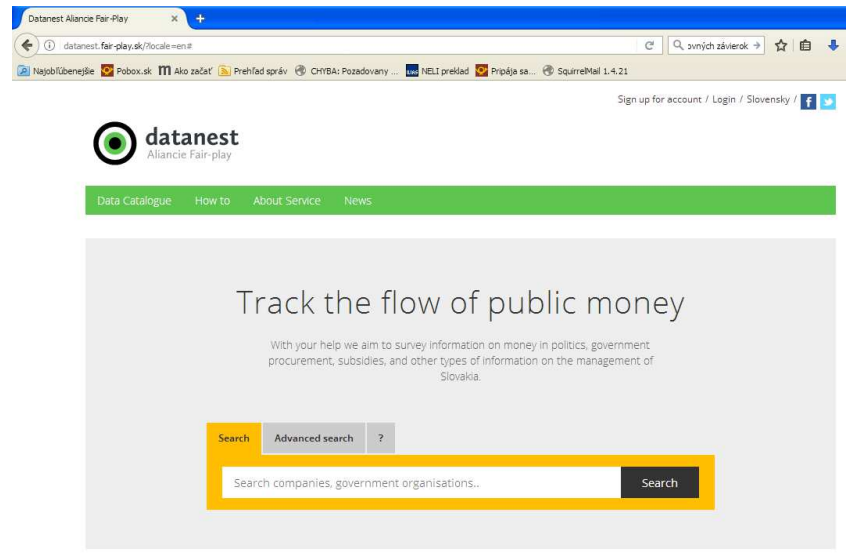

Figure 7. The English homepage of the Datanest project managed by the Fair-Play Alliance [13]

\section{b) Platform slovensko.digital (slovakia.digital)}

Slovensko.digital is a civil association aimed at enhancing the quality of digital services in Slovakia. The members of the association are mainly IT specialists. Since the start of their foundation, they have launched more successful projects. In the area of public disclosure, this is the following:

- ekosystém.slovensko.digital [14]

(ecosystem.slovakia.digital)

- verejne.digital [15] (public.digital)

\section{Ecosystem.slovakia.digital [14]}

This project is so far the most significant that the slovak.digital platform has put into operation. Includes services:

\section{- Datahub [16]}

The service provides access to consolidated and linked structured data via a simple REST API [17]. Using REST API [18] is beneficial for businesses as well as individuals who can use this data in their information systems. The user no longer has to rewrite the published data from the Internet; the service will be delivered automatically. However, the information system must be adapted to communicate with the web service. For advanced data analysis, it is also possible to access the SQL database. Registration is required here.

\section{- Open data \& API}

Open data are in this case SQL databases that are really made available to the general public and are freely available for download. Currently there are the following databases:

- Register of legal entities - database of legal persons, entrepreneurs and public authorities. There are more than 1.4 million legal entities with complete history.

Source: Register and identifier of legal entities, entrepreneurs and public authorities, Statistical Office of the Slovak Republic.

- Central Register of Contracts - database of contracts of the Central Register of Contracts since 2011.

Source: data.gov.sk, Central Register of Contracts, Office of the Government of the Slovak Republic. 
- Bulletin of Public Procurement - Public procurement database from 2014.

Source: data.gov.sk, Bulletin of Public Procurement, Office for Public Procurement.

- Commercial bulletin - database of notices from Commercial bulletin since 2011.

Source: Commercial bulletin, Ministry of Justice of the Slovak Republic.

- Register of Financial Statements - database of accounting units of the Register of Financial Statements.

Source: Register of Financial Statements, Ministry of Finance of the Slovak Republic.

- Debtors of the Social Insurance Agency - a database of social insurance debts from 2014.

Source: Debtor Lists, Social Insurance Agency.

- Debtors of the General Health Insurance Company -

Database of Debtors of the General Health Insurance Company from June 2016

Each of these databases is guided by practical and streamlined documentation (table and column descriptions). Each of them is also available with the REST API, which makes available consolidated and linked structured data in the JSON format. [19]

\section{Public digital [15]}

Homepage of Public digital is showed on the Fig.8. The service is made available in the form of a website. Its control is very intuitive and simple. The problem is that the data listed on the site is sometimes old (over 10 years old). By random check, it has been shown that e.g. the self-employed persons are looking for an address that has not only been out for years, but the trade has been abolished and the self-employed person died (a particular search - the trade was cancelled 11 years ago and the selfemployed person died 5.5 years ago). Within this project there are two more:

- links.public.digital (prepojenia.verejne.digital) - the purpose of the service is to search for links between businesses and people

\section{- procurement.public.digital}

(obstaravania.verejne.digital) - the purpose of the service is to identify and notify tenderers who should be involved in public procurement.

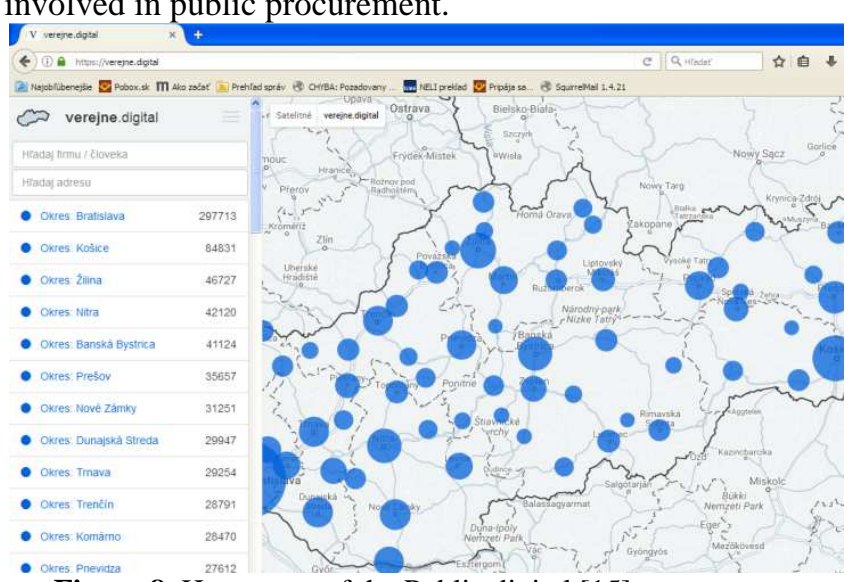

Figure 8. Homepage of the Public.digital [15]

\subsection{Enterprises}

Probably the most well-known private company that provides information on the company's finances is FinStat, Ltd.. This company was established in 2012 and the first release was launched the following year. The aim of the company is to help people simply and free to assess the financial health of Slovak businesses. The effort is to connect the data sources to one location, to process and analyze their data. At the same time, it helps to create a picture of the whole market - Slovak enterprises as a whole, individual sectors and groups of entrepreneurs.

FinStat uses data sets from up to 14 data sources. Among the most important are the following: Commercial bulletin, Business Register, Trade Register, Accounts List, Bankruptcy Register, Insurers Lists, Financial Reports, and Court Decisions. [20] Company gradually adding additional data sources, but very important information is, that only a few of these resources are free. The free information that the interested person receives is in a simplified form, and even if they are processed graphically, there is no possibility of finding a more detailed structure. If person concerned would like to buy, for example datasets, price is not published on the Internet, must contact the company. Figure 9 shows English homepage.

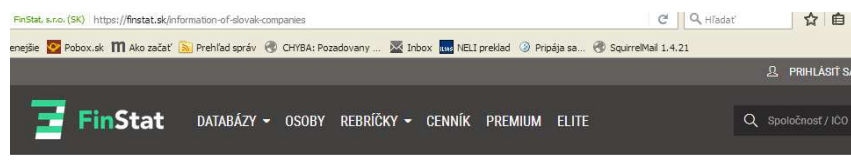

Financial information on Slovak companies in English

We provide comprehensive information about companies in Slovakia and their financial status

Qu) Finstat tok > Financial information on Sloviak comparies in Engish

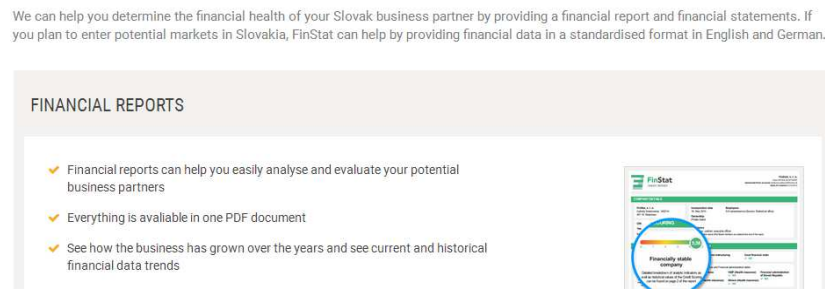

Figure 9. The English homepage of the FinStat [21]

FinStat uses data sets from up to 14 data sources. Among the most important are the following: Commercial bulletin, Business Register, Trade Register, Accounts List, Bankruptcy Register.

Second private company which provides data about Slovak enterprises is Foaf Ltd.. The name FOAF comes from the English acronym Friend Of A Friend and refers to the phenomenon of the small world networks. The project itself draws information on companies from the Slovak Commercial Register, the Business Journal, the Financial Statements Register, the database of debtors of the General Health Insurance Company, the Social Insurance and Union Insurance Company, the Financial 
A. N. Author, B. N. Author and C. N. Author

Report, the Public Procurement Bulletin and other databases. This information comes from publicly available sources, which are public administration information systems, accessible to the general public. [22]

However, the main ambition is to search for and display deeper connections between people and businesses in Slovakia using graph algorithms, so thanks to foaf.sk anyone can easily browse the social network of Slovak businesses and entrepreneurs and see the relationships between them.

As with FinStat s.r.o. Foaf provides only a fraction of the information for free, others have to buy the buyer, and the price list with the services to be paid is published on the Internet.

\section{The utility of publicly available business data}

As can be seen from the previous report, there are now enough public data providers offering information on business entities. On the one hand, there are state organizations, which by law have access to information and on the basis of Act no. 211/2000 Coll. on free access to information to the general public. The credibility of these data is high, so the entrepreneur gets the opportunity to verify the reliability of a potential partner by accessing the most common financial data, assets, liabilities, sales. The problem is that sometimes it is not possible to get to the freshest information as they are posted with a time delay.

Private companies that publish their data draw from official sources, so there is a certain time delay. On the other hand, the data is being processed (for example, Finstat compares the development of the company's financial indicators also graphically), but for more detailed data, the bidder has to redeem it.

As a second problem, it turned out that with private providers, data is not filtered and the consequence is that if someone needs to find the manager, the address or address of the entrepreneur will come across not only old but even outdated information. Random search via public.digital showed that the real estate was still featured by the owners who died or the real estate sold and can still be seen, for example, self-employed persons who have been canceled for more than 10 years. Therefore, data needs to be verified from multiple sources, and even if the provider states that it is drawing data from official sources, it is also necessary to check their timeliness.

More detailed or processed data is payable because it is time consuming to consolidate them. A good solution could be to create software that would allow data to be edited and supplemented by notes.

\section{Conclusions}

The paper deals with the most well-known and largest providers of publicly available e-data from state-owned organizations on the one hand and private providers on the other. A closer look at the information provided has highlighted a number of data issues:

- not always current,

- they are mostly informative only,

- some are so old that they no longer correspond to the truth.

Thanks to the Freedom of Information Act 2000, state entities were forced to disclose information that entrepreneurs need for their business. These data are from a reliable source, but they need to be verified or searched from multiple sources because the data found is not in the desired form. It is still true that the use of data acquired for business can be both time and costly.

There remains an open space for finding the right form of processing and consolidating such data so that the user has the data as quickly as possible, most accurately and in particular as simple as possible.

\section{Acknowledgements.}

Paper originates with the direct support of Ministry of Education of Slovak republic by grants KEGA 007TUKE-4/2018 and VEGA 1/0614/15".

\section{References}

[1] Monkova, K. et al.: Newly Developed Software Application for Multiple Access Process Planning, In: Advances in Mechanical Engineering. 2014, P. 3907139071. ISSN 1687-8132

[2] Zákon č. 211/2000 Z. z. o slobodnom prístupe k informáciám a o zmene a doplnení niektorých zákonov (zákon o slobode informácií). [online] [22.5.2017] Available at internet: http://www.zakonypreludi.sk/zz/2000-211

[3] Monka, P. et al.: Design and experimental study of turning tools with linear cutting edges and comparison to commercial tools, International Journal of Advanced Manufacturing Technology, 85 (9-12), 2016, pp. 23252343.

[4] Statistical Office of the Slovak Republic [online] [24.11.2017] Available at internet: https://slovak.statistics.sk/

[5] National Agency for Network and Electronic Services [online] [02.12.2017] Available at internet: https://data.gov.sk/en/

[6] Commercial bulletin [online] [21.11.2017] Available at internet:

https://www.justice.gov.sk/ObchodnyVestnik/Stranky/Stru kturovane-udaje.aspx

[7] Social Insurance Agency [online] [21.11.2017] Available at internet: http://www.socpoist.sk/zoznam-dlznikov-emw/

[8] Register of Financial Statements [online] [21.11.2017] Available at internet: http://www.registeruz.sk/cruzpublic/domain/accountingentity/simplesearch

[9] Register of Financial Statements [online] [21.11.2017] Available at internet: http://www.registeruz.sk/cruzpublic/home

[10] Central Register of Contracts [online] [02.12.2017] Available at internet: http://www.crz.gov.sk/ 
[11] Central Register of Contracts [online] [02.12.2017] Available at internet: http://www.crz.gov.sk/index.php?ID=114372

[12] Fair-play Alliance [online] [21.11.2017] Available at internet: http://www.fair-play.sk/abouts

[13] Datanest project [online] [02.12.2017] Available at internet: http://datanest.fair-play.sk/

[14] Ecosystem Slovakia Digital [online] [02.12.2017] Available at internet: https://ekosystem.slovensko.digital/

[15] Public digital [online] [02.12.2017] Available at internet: https://verejne.digital/

[16] Ecosystem Slovakia Digital [online] [02.12.2017] Available at internet: https://ekosystem.slovensko.digital/sluzby/datahub

[17] Wikipedia [online] [22.5.2017] Available at internet: https://en.wikipedia.org/wiki/Representational_state_transf er

[18] Ecosystem Slovakia Digital [online] [02.12.2017] Available at internet: https://ekosystem.slovensko.digital/premiove-api

[19] Wikipedia [online] [16.10.2017] Available at internet: https://cs.wikipedia.org/wiki/JavaScript_Object_Notation

[20] FinStat [online] [16.10.2017] Available at internet: www.finstat.sk

[21] FinStat [online] [16.10.2017] Available at internet: https://finstat.sk/information-of-slovak-companies

[22] Foaf Ltd. [online] [02.12.2017] Available at internet: http://foaf.sk/info/o-foaf-sk 